\title{
Young adult health literacy on health promotion as social determinant of health: Challenges for health education practice in Lithuania
}

\author{
J. Cesnaviciene, A. Kalinkeviciene, and S. Ustilaite \\ Lithuanian University of Educational Sciences, Vilnius, Lithuania
}

\begin{abstract}
A synthesis of theory, research, and practice shows that education is linked to better health through individuals' increased health knowledge and healthy behaviour. Health literacy is put forward as the central mediator between education and health. Scientific studies have shown a strong association between the levels of health literacy and health outcomes. The aim of the study is to identify the levels of health literacy on health promotion among Lithuania's young adults. The anonymous selfreported questionnaire survey was carried out in the period of 2014-2015. The research sample involved 842 young adults aged 18-29. Health literacy was measured using an HLS-EU-Q-47 questionnaire. The research studies suggest that less than half of Lithuanian young adults have sufficient or excellent health literacy on health promotion, which is essential in maintaining good health and the quality of life. These findings are important evidence that health education should become a priority area at all levels of educational process at every stage of the life: from childhood through adulthood.
\end{abstract}

Key words: health education, health literacy, young adults, Lithuania.

\section{Introduction}

Health is one of the most important multidimensional agents in the age of globalization, which determines the welfare of the society and the individual as well as the processes of state advancements. It is the high level of public health which is a prerequisite for the sustainable development of the country and the accumulation of human capital. It is acknowledged that health condition is largely influenced by the lifestyle of people themselves. Investing into the development of healthy lifestyle habits is more beneficial than paying for the treatment of an ill person. Therefore, efforts must be made that each individual would realise the influence of his lifestyle on his health and to encourage responsibility for his own health and that of others, to strengthen the motivation to develop healthy living habits. The foundations of behaviour and lifestyle, which remain for a lifetime, which in the future will determine health and quality of life of everybody, are built up in the childhood and adolescence. School, after the family, is the most important arena for health education. Coordinated formal and non-formal health education, which is based on continuity, builds students' knowledge, skills, and positive attitudes to health and healthy lifestyle. 


\subsection{Health education in the Lithuanian education system}

Health education in Lithuanian schools has come a long way over the past quarter of the century. When, after the Restoration of the independence of the Republic of Lithuania, the education reform was commenced, an important goal was established - to bring up a healthy young generation, each member of which is responsible for his health and that of other people, is able to choose an appropriate healthy lifestyle, is aware of the need to take care of his health. During the first stage of the education reform (1988-1997) the greatest attention was paid to the restructuring of the content of the education. In 1992 the first Health Education Programme [1] was prepared, which later on (in 1994 and 2000) was improved and was repeatedly published. The content of the programme covered ten topics: know yourself; personal hygiene; me and others; food and nutrition; activity, rest and physical activeness; body care; environment and health; harmful habits; substance use and abuse; family and health; diseases and their prevention. These topics were consistently repeated during the whole period of studying. When implementing the Health Education Programme it was sought to ingrain a holistic perception of health, to provide the pupils' knowledge and to develop skills, assisting in promoting their health and that of others, to develop health protection and promotion related value orientations and healthy lifestyle attitudes. The implementation of the programme was based on the principles of consistency and regularity, the differentiation of health education content, taking into consideration a pupil's age and the experience he possesses, maximum integration into the content of all the subjects of general education and non-formal education.

During the later stages of the education reform, when renewing the content of general education the mentioned Health Education Programme [1] was not renewed, however, three additional programmes were prepared. One of them is Life Skills Education Programme [2], aimed at developing the personal and social skills in pre-school children and the pupils of 1-10th forms and preparing for the living outside school and adult life. Other two programmes (Programme for Prevention of Use of Alcohol, Tobacco and Other Psychoactive Substances [3] and Preparation for Family Life and Sexuality Education Programme [4]) were compulsorily implemented at all levels of education from nursery up the 12 th form.

In 2008, when the renewal of the general education content was commenced, not only special, but also transversal competences (learning to learn, communication competence, cognitive competence, social competence, sense of initiative and creativity, personal competence, cultural competence), which empower the self-realisation of the young generation, became a priority of Lithuanian education. Health education continued to be an integral part of the content of the taught subjects, which was executed in accordance with the aforementioned programmes. And only in 2012 the new General Health Education Programme [5] was prepared, reflecting modern education paradigm, which aims at establishing a positive attitude towards health and the factors promoting it, building up healthy living habits, improving knowledge of health protection and the ways to promote it. At the level of primary education, it is recommended that this programme would be integrated into the content of the taught subjects and non-formal education. At the level of lower and upper secondary education it should be integrated into all the taught subjects and non-formal education, as well as during at least one year of schooling at every level of education (5-8th, 9-10th and 11-12th forms) health education should be taught during special lessons, which encompass the entirety of the programme. The implementation of this General Health Education Programme [5] is based on the principle of continuity, ensuring a consistent development of competences in four areas: health and healthy living concept; physical health (physical activity, healthy nutrition, activity and rest, personal and environmental cleanliness); mental health (self-esteem, emotions and feelings, mind and 
positive thinking); social health (social awareness and culture, communication, the prevention of risky behaviour).

In response to the challenges to education arising in the contemporary society, the September of 2017 marks the start of the implementation of the newest General Health and Sexuality Education and Preparation for Family Life Programme [6] in the schools of general education. It was prepared taking into consideration the opinion of scientists and health specialists, the findings of scientific research, health statistics and the recommendations of the World Health Organization and as a result of merging of the Preparation for Family Life and Sexuality Education Programme [4] and the General Health Education Programme [5], which were being implemented in schools up to that time. The objective of the latest programme is to assist pupils in acquiring the holistic understanding of health and sexuality, developing health-enhancing skills and habits, promoting responsibility for their health and that of others, encouraging them to choose a healthy lifestyle, developing an ability to create and maintain harmonious and mature interpersonal relationships. The essential aspects of the content of the programme are presented in Table 1.

Table 1. Essential aspects of the content of General Health and Sexuality Education and Preparation for Family Life Programme.

\begin{tabular}{|c|c|c|}
\hline \multicolumn{3}{|c|}{ PROGRAMME CONTENT } \\
\hline \multicolumn{3}{|c|}{ 1. Health, healthy living and family concepts } \\
\hline 2. Physical health & 3. Mental health & 4. Social health \\
\hline $\begin{array}{c}\text { Physical activity } \\
\text { Healthy nutrition } \\
\text { Harmonisation of activeness } \\
\text { and rest } \\
\text { Personal and environmental } \\
\text { cleanliness } \\
\text { Sexual maturation }\end{array}$ & $\begin{array}{c}\text { Self-esteem } \\
\text { Emotions and feelings } \\
\text { Self-control } \\
\text { Positive, constructive } \\
\text { thinking and self-expression }\end{array}$ & $\begin{array}{c}\text { Friendship and love resilience } \\
\text { to risky behaviour }\end{array}$ \\
\hline \multicolumn{3}{|c|}{ PROGRAMME OUTCOME } \\
\hline Health education & Sexuality education & Preparation for family life \\
\hline $\begin{array}{l}\text { Healthy living (lifestyle, the } \\
\text { entirety of daily habits, which } \\
\text { assist in maintaining and } \\
\text { promoting health) }\end{array}$ & $\begin{array}{l}\text { Perception of innate sexual } \\
\text { identity, responsible sexual } \\
\text { behaviour, which means an } \\
\text { ability, based on volition and } \\
\text { motivation, to choose, for self } \\
\text { and another person, the safest } \\
\text { (in a physical and mental } \\
\text { sense) sexual behaviour, } \\
\text { encompassing respect for self } \\
\text { and another person, the } \\
\text { realisation of the } \\
\text { consequences of a risky } \\
\text { sexual behaviour }\end{array}$ & $\begin{array}{l}\text { Ability to create and maintain } \\
\text { interpersonal relationships, } \\
\text { facilitating a mature friendship } \\
\text { and love in order to } \\
\text { consummate it in marriage and } \\
\text { to create a harmonious family }\end{array}$ \\
\hline
\end{tabular}

It is recommended that the General Health and Sexuality Education and Preparation for Family Life Programme [6] would be implemented in a joined effort of a school and family (parents or guardians) through the collaboration of the teachers of different subjects and other education professionals and the participation of non-governmental organisations and healthcare specialists. The implementers of the programme are advised to follow the implementation guidelines of the General Health Education Programme [5], which had been executed up to that point. In addition to this compulsory programme, schools may optionally implement preventive programmes accredited by the National Centre for Special 
Needs Education and the Psychology Centre as well: an early prevention programme "Zippy's Friends" and "Apple's Friends"; Child's Emotional Competences Training Programme; the programme "Second Step" to develop social-emotional skills; a preventive program "Unplugged"; Olweus bullying prevention programme; an alcohol, tobacco and other drug use prevention programme "Snowball"; LIONS QUEST Life Skills education programme "The Crossroads of Adolescence".

It should be noted that some Lithuanian schools of general education have been participating in the activities of the European Network of Health Promoting Schools or the national network since 1993. Scientific research [7, 8] has concluded that those are the schools, in which complex and coordinated health promotion is more often integrated into the system of general education. Compared with the schools in which targeted health education activity was not performed, the schools promoting health show positive changes towards healthy living among pupils: the obvious tendencies of healthier food consumption, increased levels of pupils' physical activity, lower levels of alcoholic beverages consumption, greater attention to oral hygiene. Recent scientific evidence [7, 8] showed that health promoting school concept is acceptable for the schools of general education; health promotion activity, which is based on it, is effective and can be used for the further development of the activity in order to engage more schools of general education into the national network of health promoting schools.

The review of health education programmes shows that, in Lithuanian education system, conditions have been established for the formation of healthy living of the young generation. It is corroborated by the experience of the schools, which participate in the network of health promoting schools. However, the findings of the scientific research indicate that the schools of general education still "lack coherent development of social skills, too little importance is still given to the building up of healthy living habits. The general view is that the priority of school activity is to prepare pupils for the final examination, whereas the implementation of health education by teachers is marked by fragmentation" [9, p. 147].

\subsection{Health literacy as a multidimensional concept in health education}

Since the end of the 20th century in different countries around the world, health literacy has become an important precondition for social and economic development of society. It is necessary for the daily ability of people to manage their health, healthy living and the quality of life, which depends on them. According to L. Kannas [10, p. 13], "improving people's health literacy across the lifespan has become an important health promotion approach in order to support healthy development in childhood and healthy ageing". High or low literacy levels have different impacts, notably on the individual's health. There is an increasing scientific evidence that the general health status of the people, whose health literacy is at a low level, is lower [11-14], their living is less healthy [15, 16], they have a lower preventive measures and services take-up $[15,17]$, their capacities to manage chronic diseases and to remember or to understand the information presented by the medical personnel are insufficient $[18,19]$; such people are more prone to make mistakes when taking their medicines or to adhere to other instructions of the doctors [12, 20,21].

One of the first health literacy concepts reflects traditional literacy and encompasses an individual's ability to perform tasks, requiring reading and arithmetic skills, related to information on health $[22,23]$. However, over time, such narrow approach towards this concept was changing. One of the health literacy concepts, which is most frequently mentioned in scientific literature and recognised at international level, was proposed in 1998 by the World Health Organisation. The complemented Health Promotion Glossary points out that these are the "cognitive and social skills which determine the motivation and 
ability of individuals to gain access to, understand and use information in ways which promote and maintain good health" [24, p. 10].

Foreign scientific literature abounds with the diversity of concepts on health literacy. Having analysed them, the scientists [25-28] show that this concept is expanding from a narrow immutable understanding towards a renewing and multidimensional concept, which changes all lifelong. It is gradually changing from an individual towards communal level. One of the latest health literacy concepts is based on the systematic analysis and conceptualisation of the definitions presented in scientific literature: "health literacy is linked to literacy and entails people's knowledge, motivation and competences to access, understand, appraise, and apply health information in order to make judgments and take decisions in everyday life concerning healthcare, disease prevention and health promotion to maintain or improve quality of life during the life course" [28, p. 3]. In other words, the multidimensional concept of health literacy reflects a complex approach that combines four information processing stages (access, understand, appraise, apply) and three health relevant areas (health care, disease prevention, health promotion). In healthcare, health literacy is linked to a personal ability to extract information on medicine, to understand, to interpret and to appraise it and to make informed decisions and to adhere to the advice of healthcare specialists. Health literacy in disease prevention is an opportunity to receive and to understand, to interpret and to appraise information on health risk factors, to reach sound decisions regarding the management of health risk factors. In health promotion, health literacy is important as an ability to constantly renew, to realise, to interpret and to appraise information on social and environmental factors, which determine health, capacity to take sound decisions regarding the factors, which influence health. Consequently, health literacy is becoming an important contribution to the empowerment of people in the areas of healthcare, diseases prevention and health promotion.

There is no lack of research on health literacy abroad. However, there is a lack of sufficient research in Lithuania. Two more exhaustive studies published in the Lithuanian language can be mentioned: D. Zagurskiene "The Evaluation of Patients' Health Literacy" [18] and Z. Javtokas "Overview of the Research Data on Health Literacy of Lithuanian Population" [29]. Similar studies have not so far been conducted among Lithuanian young adult population. Therefore, it is becoming important to research and to analyse what level of health literacy the young adults, having graduated from schools of general education, possess.

The aim of the study is to identify the specific characteristics of health literacy of young adults and to reveal health literacy in health promotion as a challenge to health education.

\section{Materials and methods}

\subsection{Research instrument}

Subjective health literacy was measured using an HLS-EU-Q-47 questionnaire [30]. With the agreement of the HLS-EU Project coordinator K. Sørensen, the HLS-EU-Q-47 questionnaire was translated from English into the Lithuanian language using the translation-back-translation method. The questionnaire was pre-tested for comprehension and completeness. To explore internal consistency of the questionnaire, Cronbach's alpha was calculated. The analysis showed that Cronbach's alpha was satisfactory (Cronbach's $\alpha$ $=0.94$ respectively). In total, the HLS-EU-Q-47 questionnaire comprised 47 items which explored four dimensions of health literacy: access, understanding, appraisal and application of health information in three different domains: health care (16 items), disease prevention (16 items) and health promotion (15 items). The respondents were asked to 
report on 47 items using a four-point Likert scale $(1=$ very difficult, $2=$ difficult, $3=$ easy, and 4 = very easy). The "I don't know" answer option was used when stated spontaneously and coded as a missing value.

Demographic characteristics measured via the questionnaire included age (year), gender (male, female).

\subsection{Characteristics of the research sample}

According to the statistical information of Statistics Lithuania

(http: / /www.stat.gov.1t), on January 1, 2014, 482,142 young adults aged 18-29

(247,578 males and 234,564 females) lived in Lithuania. The research sample was

determined using sample size calculator

(http: / / www. surveysystem.com/sscalc.htm). Having conducted calculations, it was determined that 798 respondents (399 males and 399 females) was a sufficient research sample that would represent the general population of 18-29 year old young adults.

The final study random sample was composed by 842 young adults, who voluntarily decided to participate. Data were collected during the period of 2014-2015. The paper-andpencil questionnaire or online questionnaire was completed anonymously, and the participants were assured of data confidentiality. Table 2 presents the characteristics of the study sample.

Table 2. Distribution of sample by age group and gender.

\begin{tabular}{|c|c|c|c|c|c|c|}
\hline \multirow{2}{*}{ Age group } & \multicolumn{2}{|c|}{ Male $(\boldsymbol{N}=\mathbf{4 1 4})$} & \multicolumn{2}{c|}{ Female $(\boldsymbol{N}=\mathbf{4 2 8})$} & \multicolumn{2}{c|}{ Total $(\boldsymbol{N}=\mathbf{8 4 2})$} \\
\cline { 2 - 7 } & $\boldsymbol{N}$ & $\mathbf{\%}$ & $\boldsymbol{N}$ & $\mathbf{\%}$ & $\boldsymbol{N}$ & $\mathbf{\%}$ \\
\hline $18-19$ & 143 & 34.5 & 89 & 20.8 & 232 & 27.5 \\
\hline $20-24$ & 144 & 34.8 & 190 & 44.4 & 334 & 39.7 \\
\hline $25-29$ & 127 & 30.7 & 149 & 34.8 & 276 & 32.8 \\
\hline
\end{tabular}

\subsection{Data analysis}

The data was analyzed using SPSS version 17.0. The following methods were applied to analyse the research data: descriptive analysis (frequencies, percentage), Pearson's Chisquare tests (nonparametric test was used to compare health literacy levels between two groups - young men and young women), Cronbach's alpha was used to test the reliability of the questionnaire scores and measure the internal consistency of propositions. The statistically significant value was set at $p<0.05$.

Health literacy index scores for three scale (health care, disease prevention, and health promotion) and general health literacy index were standardized on a metric scale between 0 (lowest level of health literacy) and 50 (best level of health literacy) and constructed using the formula [30]:

$$
I=(X-1) \times \frac{50}{3}
$$

In this formula, $I$ - health literacy index, $X$ - mean of all participating items for each individual.

The study participants were divided into 4 groups, which reflected their health literacy abilities. Group 1 (inadequate health literacy) included people who scored between 0-25, group 2 (problematic health literacy) people who scored between 25.01-33, group 3 
(sufficient health literacy) people who scored between 33.01-42, and group 4 (excellent health literacy) people.

\section{Results and discussion}

\subsection{Young adult health literacy by gender}

As has already been mentioned, using HLS-EU-Q-47 questionnaire it is possible to find out general health literacy, health literacy on health care, health literacy on disease prevention, and health literacy on health promotion. Analysing the findings of the study, which are presented in Table 3, it is noted that, when it comes to the levels of health literacy, the percentage frequencies of the young men and the young women are similar, no statistically significant difference has been established.

Thus, having generalised the research results, it is possible to state that persons with sufficient or excellent levels of health literacy on health care made up $30.2 \%$ and $9.5 \%$ of the total, respectively. This study showed that $13.7 \%$ of the young adults had excellent health literacy on disease prevention, and $33.8 \%$ of the young adults had sufficient health literacy in this area. Analysing the respondents' replies about health literacy on health promotion, it is possible to claim that only two-fifths of the young adults had sufficient or excellent health literacy on health promotion.

Table 3. Distribution of young adults by levels of health literacy and gender (\%).

\begin{tabular}{|c|c|c|c|c|}
\hline & $\begin{array}{c}\text { Health } \\
\text { literacy levels } \\
\end{array}$ & $\begin{array}{c}\text { Male } \\
(N=414) \\
\end{array}$ & $\begin{array}{c}\text { Female } \\
(N=428) \\
\end{array}$ & $\begin{array}{c}\text { Total } \\
(N=842) \\
\end{array}$ \\
\hline \multirow{4}{*}{ Health literacy on health care } & Inadequate & 20.5 & 18 & 19.2 \\
\hline & Problematic & 39.9 & 42.3 & 41.1 \\
\hline & Sufficient & 30.2 & 30.1 & 30.2 \\
\hline & Excellent & 9.4 & 9.6 & 9.5 \\
\hline \multirow[t]{4}{*}{ Health literacy on disease prevention } & Inadequate & 18.3 & 15.2 & 16.7 \\
\hline & Problematic & 35.3 & 36.2 & 35.8 \\
\hline & Sufficient & 32.9 & 34.8 & 33.8 \\
\hline & Excellent & 13.5 & 13.8 & 13.7 \\
\hline \multirow[t]{4}{*}{ Health literacy on health promotion } & Inadequate & 23.2 & 25.2 & 24.2 \\
\hline & Problematic & 37.7 & 34.6 & 36.2 \\
\hline & Sufficient & 27.8 & 30.8 & 29.3 \\
\hline & Excellent & 11.3 & 9.4 & 10.3 \\
\hline \multirow[t]{4}{*}{ General health literacy } & Inadequate & 20.8 & 16.6 & 18.6 \\
\hline & Problematic & 38.2 & 41.8 & 40 \\
\hline & Sufficient & 34 & 33.9 & 34 \\
\hline & Excellent & 7 & 7.7 & 7.4 \\
\hline
\end{tabular}

Having calculated the index of general health literacy of young adults, it was determined that $18.6 \%$ respondents had inadequate, $40 \%$ - problematic, $34 \%$ - sufficient and $7.4 \%$ had excellent general health literacy. The results of this study can be compared with the results obtained by European Health Literacy Survey [30]. The obtained data were similar to the ones obtained in Austria, Bulgaria and Spain. However, the number of Lithuanian young adults that were characterised by sufficient or excellent levels of health literacy was lower than in Germany, Greece, Ireland, Netherlands and Poland [30]. However, the comparison of such results is only partly possible, because it must be noted that the age of the respondents in the study on health literacy, which was conducted in eight European countries, was 15-year olds and older. 


\subsection{Young adult's health literacy on health promotion}

Our article provides a more in-depth analysis of young adult health literacy on health promotion. As already been mentioned, only $10.3 \%$ of the young adults have excellent health literacy on health promotion, whereas $29.3 \%$ - sufficient (Table 3).

Although information and theoretical knowledge are not a sufficient reason to change one's lifestyle or promote health, it is affirmed that the possession of theoretical knowledge provides an opportunity to achieve a better understanding of the influence of a lifestyle on health. Consequently, in order to promote one's own health, it is firstly necessary to acquire the knowledge necessary for that. The data of the study revealed that the majority of the young adults, who participated in the study, find it easy to extract information on a healthy lifestyle (exercising, healthy nutrition and the like), as well as ways to promote emotional health. However, only half of the respondents pointed out that they found it easy to extract information on possibilities for health promotion in their closest environment. Less than half of the respondents pointed out that they found it easy to extract information on how people in their community would be able to live healthier, information on health policy changes, which may influence their health. Summarising the data of the study it can be presumed that only $48.3 \%$ of the young adults possess sufficient or excellent ability to update themselves on determinants of health in the social and physical environment. The capacities of the rest of the young adults are either problematic or inadequate.

Unfortunately, the acquisition of information and knowledge is not a sufficient prerequisite for one's lifestyle to change. Only having realised the obtained information, having embraced the notion of the conveyed knowledge, it is possible to build up healthy living skills and attitude, which will determine the behaviour, which is favourable to health. On the basis of the findings of the study, it was established that the majority of the young adults found it easy to understand the advice of their family members or friends, or the information presented in the media how to promote health. However, only slightly more than half of the respondents agreed that they found it easy to understand the information given on food labels or the information on how to safeguard mental health. Consequently, summarising it can be presumed that only half of the young adults, who participated in the study, possess excellent or sufficient abilities to understand information.

The ability to critically analyse and appraise health-related information, to interpret it is becoming particularly important where contemporary youth is concerned. The media (the internet, the press, television) present expressive and abundant textual information and images, which, beyond reasonable doubt, influence the learning on health and healthy living of those, who live in the digital world. Therefore, the critical selection and appraisal of health-related information are becoming inextricably linked to health promotion. The majority of the young adults, who participated in the study, concurred that they find it easy to appraise how and what daily behaviour of theirs determines health and well-being and how their present living conditions assist in safeguarding health. Consequently, the study established that $74.8 \%$ of the young adults possess sufficient or excellent abilities to interpret and evaluate information on health determinants in the social and physical environment.

The critical appraisals of the information on health create prerequisites to change one's lifestyle and to reach appropriate decisions regarding health. $73.4 \%$ of the young adults, who participated in the study, pointed out that they find it easy make decisions how to promote their health. And although three-fifths of the young adults (more young men than young women, $\chi^{2}=21.050 ; p<0.0001$ ) identified that they found it easy to go to a sports club, discotheque or take up another physical activity, however, only half of the young adults concurred that they found it easy to change their living conditions, in order to influence health and well-being (there were more young women, who pointed out that they 
find difficulty doing that, than young men, $\chi^{2}=11.973 ; p<0.05$ ). Even fewer of the respondents pointed out that they found it easy to participate in the activity of their local community, which influences health. Based on such results it can be presumed that only $39 \%$ of the young adults, who participated in the study, possess an excellent or sufficient ability to make informed decisions. There were more young women, whose abilities are insufficient, than young men $\left(\chi^{2}=15.031 ; p<0.01\right)$.

Consequently, summarising the results of the study, it can be presumed that the health promotion, which is executed in schools, does not yet ensure the development of the abilities of a sufficient level. It poses a particular challenge to the educators and family of the generation, which is growing up.

\section{Conclusions}

The new conception of health literacy involves abilities to access, understand, appraise and apply information across the domains of health care, disease prevention and health promotion. Having generalised the research results, it is possible to claim that less than half of Lithuanian young adults have sufficient or excellent health literacy on health promotion, which is essential in maintaining good health and improving the quality of life. These findings are important evidence that health education should become a priority area at all levels of educational process at every stage of the life: from childhood through adulthood.

This study was funded by the Research Foundation of Lithuanian University of Educational Sciences.

\section{References}

1. A. Davidavičienè. Sveikatos ugdymo programa. Universalios ugdymo programos. 62-81 (1992). (In Lithuanian)

2. L. Bulotaitè, V. Gudžinskienè. Gyvenimo ịgūdžiu ugdymo programa (2003).

Available at

http://www.smm.1t/web/lt/pedagogams/ugdymas/ugdymo_prog

(In Lithuanian)

3. Alkoholio, tabako ir kitų psichiką veikiančių medžiagų vartojimo prevencijos programa (2006). Available at

http://www.smm.1t/web/lt/pedagogams/ugdymas/ugdymo_prog (In Lithuanian)

4. Rengimo šeimai ir lytiškumo ugdymo programa (2007). Available at http://www.smm.1t/web/It/pedagogams/ugdymas/ugdymo_prog (In Lithuanian)

5. Sveikatos ugdymo bendroji programa (2012). Available at http://wWw.smm.1t/web/lt/pedagogams/ugdymas/ugdymo_prog (In Lithuanian)

6. Sveikatos ir lytiškumo ugdymo bei rengimo šeimai bendroji programa (2016). Available at http://www.smm.1t/web/lt/pedagogams/ugdymas/ugdymo_prog (In Lithuanian)

7. L. Stankevičienè, A. Zaborskis. Sveikatą stiprinančių Lietuvos mokyklų moksleivių gyvensena ir sveikata. Medicina, 35, 780-787 (1999). (In Lithuanian)

8. A. Jociute. Sveikatos stiprinimo ir ugdymo veiklos veiksmingumo Lietuvos bendrojo lavinimo mokyklose jvertinimas: daktaro disertacija (2002). (In Lithuanian)

9. A. Petrauskienè, S. Ustilaitè. Mokyklos sveikatos ugdytojų vaidmenys (2013). (In Lithuanian) 
10. L. Kannas. Health Education as a stand-alone School Subject to improve Health Literacy of Future Generations: Lessons to learn from Finland. 8th Nordic Health Promotion Research Conference: abstract book. (2016). Available at https://www.jyu.fi/sport/laitokset/terveys/en/NHPRC

11. Agency for Healthcare Research and Quality. Health Literacy Universal Precautions Toolkit (2010). Available at http: / / www . ahrq.gov/qual/literacy/

12. N.D. Berkman, S.L. Sheridan, K.E. Donahue, D.J. Halpern, \& K. Crotty. Limited health literacy and health outcomes: An updated systematic review. Ann Intern Med 155(2), 129-130 (2011)

13. A.E. Schnitzer, M. Rosenzweig, \& B. Harris. Health Literacy: A Survey of the Issues and Solutions. J Consum Health Internet 15(2), 164-179 (2011)

14. R. Mottus, C. Murray, J.M. Staff, W. Johnson, M.S. Wolf, I.J. Deary. Towards understanding the links between health literacy and physical health. Health Psychol 33, 164-173 (2014)

15. S. White, J. Chen, \& R. Atchison. Relationship of preventive health practices and health literacy: A national study. Am J Health Behav 32(3), 227-242 (2008)

16. I.M. Bennett, J. Chen, J.S. Soroui, \& S. White. The contribution of health literacy to disparities in self-rated health status and preventive health behaviors in older adults. Ann Fam Med 7, 204-211 (2009)

17. Y.I. Cho, S.Y. Lee, A.M. Arozullah, \& K.S. Crittenden. Effects of health literacy on health status and health service utilization amongst the elderly. Soc Sci Med 66, 1809-1816 (2008)

18. D. Zagurskienè. Pacientu sveikatos raštingumo vertinimas: daktaro disertacija (2009). (In Lithuanian)

19. D. Zagurskienè, I. Misevičienè. Slaugytojų nuomonè apie pacientų sveikatos mokymą ir savo žinių sveikatos klausimais vertinimą. Sveikatos mokslai 21(5), 191195 (2011). (In Lithuanian)

20. S. Kripilani, M.E. Gatti, \& T.A. Jacobsen. Association of age, health literacy, and medication management strategies with cardiovascular medication adherence. Patient EducCouns 81, 177-181 (2010)

21. J.L. Lenahan, D.M. McCarthy, \& T.C. Davis. A drug by any other name: patients' ability to identify medication regimens and its association with adherence and health outcomes. J Health Commun 18, 31-39 (2013)

22. R.M. Parker, D.W. Baker, M.V. Williams, \& J.R. Nurss. The Test of Functional Health Literacy in Adults (TOFHLA): a new instrument for measuring patient's literacy skills. J Gen Intern Med 10, 537-542 (1995)

23. M.V. Williams, R.M. Parker, D.W. Baker, N.S. Parikh, K. Pitkin, W.C. Coates, \& J.R. Nurss. Inadequate functional health literacy among patients at two public hospitals. JAMA 274, 1677-1682 (1995)

24. World Health Organization. Health Promotion Glossary (1998). Available at http://apps.who.int/iris/handle/10665/64546

25. B. Kwan, J. Frankish, \& I. Rootman. The development and validation of measures of "health literacy" in different populations (2006)

26. N.D. Berkman, T.C. Davis \& L. McCormack. Health Literacy: What Is It? J Health Commun 15(S2), 9-19 (2010)

27. R. Marks. Health Literacy and School-Based Health Education (2012)

28. K. Sørensen, S. van den Broucke, J. Fullam, G. Doyle, J. Pelikan, Z. Slonska, \& H. Brand. Health literacy and public health: A systematic review and integration of definitions and models. BMC Public Health 12(1), 80 (2012) 
29. Z. Javtokas. Lietuvos gyventojų sveikatos raštingumo tyrimo duomenų apžvalga (2012). Available at http://www.smlpc.lt/media/file/SMLPCinformacija/Veikla/Tyrimai-analizes/

Sveikatos20rastingumas-2012.pdf (In Lithuanian)

30. HLS-EU Consortium. Comparative report of health literacy in eight EU member states. The European Health Literacy Survey HLS-EU (2012). Available at http://www.health-literacy.eu 
